\title{
Policy Analysis: Valuation of Ecosystem Services in the Southern
}

\section{Appalachian Mountains}

H. Spencer Banzhaf, Dallas Burtraw, Susie Chung Criscimagna, Bernard J. Cosby, David A.

Evans, Alan J. Krupnick, and Juha V. Siikamäki

\section{Supporting Information}

Table of Contents

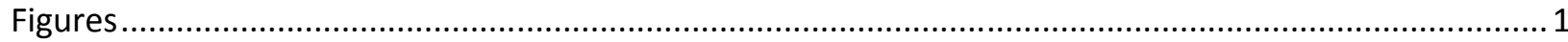

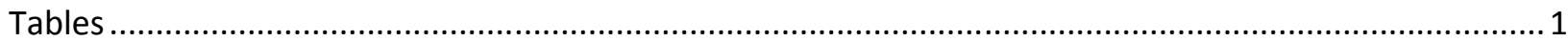

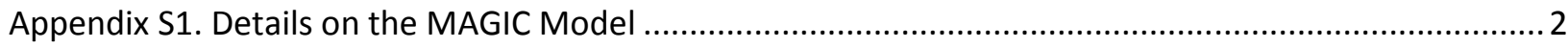

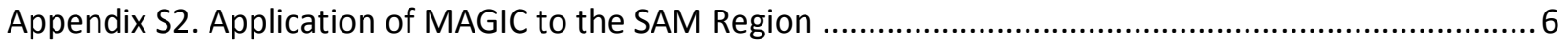

Appendix S3. Willingness to Pay for Ecosystem Improvements ..........................................................12

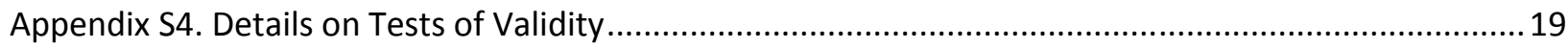

\section{Figures}

Figure S2-1: Cumulative ANC Distribution of Non-Naturally Acidic (ANC $<50 \mu \mathrm{eq} / \mathrm{L}$ ) Representative Streams in Sample for a Subset of Deposition Scenarios

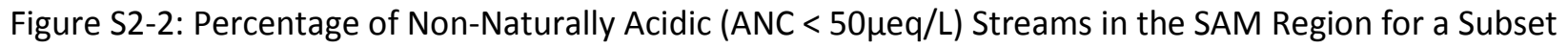
of Deposition Scenarios

\section{Tables}

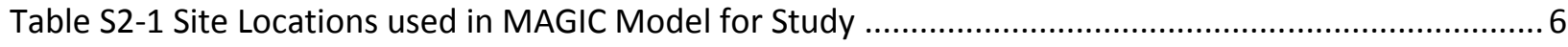

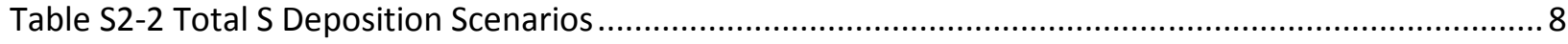

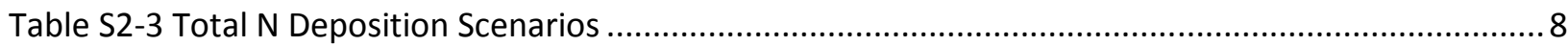

Table S3-1. Estimated Utility Parameters and Willingness to Pay .........................................................15

Table S4-1. Percent Supporting program by Bid and Scope in Raw Data ...............................................22

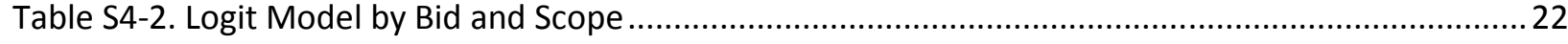

Table S4-3. Tests of Construct Validity and Demographic Interactions..................................................23 


\section{Appendix S1. Details on the MAGIC Model}

The Model for Acidification of Groundwater In Catchments (MAGIC) is a lumpedparameter model of intermediate complexity, developed to predict the long-term effects of acidic deposition on soil and surface water chemistry. ${ }^{1,2}$ The degree and rate of change of surface water acidity depend both on flux factors and the inherent characteristics of the affected soils.

Cation exchange is modeled using equilibrium (Gaines-Thomas) equations with selectivity coefficients for each base cation and Al. Sulfate adsorption is represented by a Langmuir isotherm. Aluminum dissolution and precipitation are assumed to be controlled by equilibrium with a solid phase of $\mathrm{Al}(\mathrm{OH})_{3}$. Aluminum speciation is calculated by considering hydrolysis reactions as well as complexation with $\mathrm{SO}_{4}{ }^{2-}$ and $\mathrm{F}^{-}$. Effects of $\mathrm{CO}_{2}$ on $\mathrm{pH}$, and the speciation of inorganic $\mathrm{C}$ is computed from equilibrium equations. Organic acids are represented in the model as tri-protic analogues. First-order rates are used for biological retention (uptake) of $\mathrm{NO}_{3}$ and $\mathrm{NH}_{4}{ }^{+}$in the soils and streams. The rate constants are not varied during the simulation period. Weathering rates for base cations are assumed to be constant. A set of mass balance equations for base cations and strong acid anions is included.

Given a description of the historical deposition at a site, the model equations are solved numerically to give long-term reconstructions of surface water chemistry (for complete details of the model, see Cosby ${ }^{1,2,3,4}$ ). MAGIC has been used to reconstruct the history of acidification and to simulate the future trends on a regional basis and in a large number of individual watersheds in both North America and Europe. , $5,6,7,8,9,10,11,12,13,14,15^{-15}$

The aggregated nature of the MAGIC model requires that it be calibrated to observed data from a system before it can be used to examine potential system response. Calibration is achieved by setting the values of certain parameters within the model that can be directly measured or observed in the system of interest (called fixed parameters). The model is then run 
using observed and/or assumed atmospheric and hydrologic inputs, and the outputted stream water and soil chemical variables (called criterion variables) are compared with observed values of these variables. If the observed and simulated values differ, the values of another set of parameters in the model (called optimized parameters) are adjusted to improve the fit. After a

number of iterations adjusting the optimized parameters, the simulated-minus-observed values of the criterion variables usually converge to zero (within some specified tolerance). The model is then considered calibrated.

The weathering and selectivity coefficient of each of the four base cations are optimized. Field measurements are used to drive the estimates of the current soil exchangeable pool size and current output flux of each of the four base cations.

\section{Appendix S1 References}

(1) Cosby, B. J.; Wright, R. F.; Hornberger, G. M.; Galloway, J. N. Modelling the effects of acid deposition: Assessment of a lumped parameter model of soil water and streamwater chemistry. Water Resources Research 1985, 21, 51-63.

(2) Cosby, B. J.; Wright, R. F.; Hornberger, G. M.; Galloway, J. N. Modelling the effects of acid deposition: Estimation of long-term water quality responses in a small forested catchment. Water Resources Research 1985, 21, 1591-1601.

(3) Cosby, B. J.; Ferrier, R. C.; Jenkins, A.; Wright, R. F. Modelling the effects of acid deposition: refinements, adjustments and inclusion of nitrogen dynamics in the MAGIC model. Hydrology and Earth System Sciences 2001, 5, 499-517. 
(4) Cosby, B. J.; Hornberger, G. M.; Ryan, P. F.; Wolock, D. M. MAGIC/DDRP Final Report, Project Completion Report. US Environmental Protection Agency: Corvallis, OR, 1989.

(5) Cosby, B. J.; Jenkins, A.; Ferrier, R. C.; Miller, J. D; Walker, T. A. B. Modelling stream acidification in afforested catchments: long-term reconstructions at two sites in central Scotland. Journal of Hydrology 1990 120, 143-162.

(6) Cosby, B. J.; Norton S. A; Kahl, J. S. Using a paired-catchment manipulation experiment to evaluate a catchment-scale biogeochemical model. Science of the Total Environment 1996, 183, 49-66.

(7) Hornberger, G. M.; Cosby, B. J.; Wright, R. F. Historical reconstructions and future forecasts of regional surface water acidification in southernmost Norway. Water Resources Research 1989, 25, 2009-2018.

(8) Jenkins, A.; Cosby, B. J.; Ferrier, R. C.; Walker, T. A. B.; Miller, J. D. Modelling stream acidification in afforested catchments: an assessment of the relative effects of acid deposition and afforestation. Journal of Hydrology 1990 120, 163-181.

(9) Jenkins, A.; Whitehead, P. G.; Cosby, B. J.; Birks H. J. B. Modelling Long-term acidification: a comparison with diatom reconstructions and the implication for reversibility. Philosophical Transactions of the Royal Society of London 1990, 327, 435-440.

(10) Jenkins, A.; Whitehead, P. G.; Musgrove, T. J.; Cosby, B. J. A regional model of acidification in Wales. Journal of Hydrology 1990, 116, 403-416.

(11) Wright, R. F.; Cosby, B. J.; Flaten, M. B.; Reuss, J. O. Evaluation of an acidification model with data from manipulated catchments in Norway. Nature 1990, 343, 53-55. 
(12) Wright, R. F.; Lotse, E.; Semb, E. Experimental acidification of alpine catchments at Sogndal, Norway: Results after 8 Years. Water, Air, and Soil Pollution 1994, 72, 297-315.

(13) Norton, S. A; Wright, R. F.; Kahl, J. S.; Schofield, J. P. The MAGIC Simulation of Surface Water at, and First Year Results from, the Bear Brook Watershed Manipulation, Maine, USA. Environmental Pollution 1992 77, 279-286.

(14) Sullivan, T. J.; Cosby, B. J. Modeling the concentration of aluminum in surface waters. Water, Air, and Soil Pollution 1998, 105, 643-659.

(15) Sullivan, T. J.; Cosby, B. J.; Herlihy, A. T.; Webb, J. R.; Bulger, A. J.; Snyder, K. U.; Brewer, P. F.; Gilbert, E. H.; Moore, D. L. Regional model projections of future effects of sulfur and nitrogen deposition on streams in the southern Appalachian Mountains. Water Resources Research 2004, 40. 


\section{Appendix S2. Application of MAGIC to the SAM Region}

MAGIC forecasts future conditions at 169 sites (Table S2-1). These sites are representative of wild trout streams in the SAM region, most of which are at high elevation ( $>3000$ feet) and undisturbed by agricultural activity. Information from the 169 sites used to calibrate the model were collected for studies for the U.S. Forest Service and the Southern Appalachian Mountain Initiative. The sites are all from our study area or from neighboring states (Alabama and South Carolina). This sample of streams represents about 40 percent of all streams (by length) in our study region. ${ }^{1}$

Table S2-1 Site Locations used in MAGIC Model for Study

\begin{tabular}{lll}
\hline State & Number of Sites & Location \\
\hline VA & 62 & Class I (5), EMAP (6), VTSSS (51) \\
WV & 26 & Class I (16), EMAP (10) \\
NC & 50 & Class I (5), Pisgah (29), Nantahala (16) \\
TN & 21 & Class I (3), Cherokee (18) \\
GA & 4 & Class I (4) \\
SC & 3 & Sumter (3) \\
AL & 3 & Class I (3) \\
\hline \hline
\end{tabular}

* The value in parenthesis is the number of sites from each location. Class 1 indicates that the site is in a National Park in the state. Proper names refer to the National Forests. EMAP sites are those in the U.S. Environmental Protection Agency's Environmental Monitoring and Assessment Program. VTSSS sites are those in University of Virginia's Virginia Trout Stream Sensitivity Study. 
Tables S2-2 and S2-3 describe the dimensions for the levels of assumed sulfur (S) and nitrogen (N) deposition in the 32 scenarios evaluated using MAGIC. There are eight $\mathrm{S}$ deposition scenarios that are each combined with four $\mathrm{N}$ deposition scenarios.

In the scenarios historical deposition patterns (1860 - 1980) were based on Advanced Statistical Trajectory Regional Air Pollution (ASTRAP) model simulations for all scenarios. Deposition patterns from 1980 to 1990 (if needed) were also based on ASTRAP model simulations, while deposition patterns from 1990 to 2000 (if needed) were based on National Atmospheric Deposition Program (NADP) observed wet deposition. For the scenarios involving changes relative to year 2000 levels, the changes from 2000 to 2007 were based on NADP observed wet deposition. For those scenarios deposition from 2007 to 2010 was assumed constant at 2007 levels. If further deposition changes were necessary after 2010 to reach the target 2020 level relative to 2000 , the additional change was implemented linearly between 2010 and 2020. For all scenarios, deposition was held constant after the last specified change until the year 2100 .

In addition to these 32 scenarios, a scenario was evaluated assuming that historically there has been no man-made deposition, which identifies the share of streams in the sample that

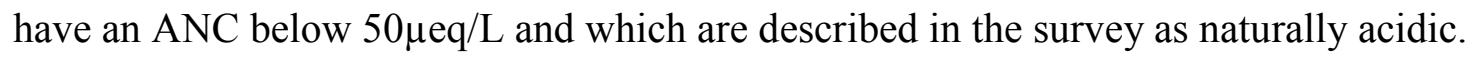

The combination of scenarios S5 and N2 is most like the scenario expected from Title IV of the Clean Air Act. The combination of scenarios S6 and N2 is most like the conditions expected from the CAIR (as well as its replacement Cross-State Air Pollution Rule). 


\section{Table S2-2 Total S Deposition Scenarios}

\begin{tabular}{ll}
\hline \hline S Scenario & $\mathrm{SO}_{4}$ Changes \\
\hline S1 & Historic to 1980 levels and constant thereafter \\
S2 & Historic to 1990 levels and constant thereafter \\
S3 & Historic to 2000 levels and constant thereafter \\
S4 & Historic to 2007 levels, reduced to $80 \%$ of 2000 levels by 2020, constant thereafter. \\
S5 & Historic to 2007 levels, reduced to $60 \%$ of 2000 levels by 2020, constant thereafter. \\
S6 & Historic to 2007 levels, reduced to $40 \%$ of 2000 levels by 2020, constant thereafter. \\
S7 & Historic to 2007 levels, reduced to $20 \%$ of 2000 levels by 2020, constant thereafter. \\
S8 & Historic to 2007 levels, reduced to $3 \%$ of 2000 levels by 2020, constant thereafter. \\
\hline \hline
\end{tabular}

Table S2-3 Total N Deposition Scenarios

\begin{tabular}{|c|c|c|}
\hline N Scenario & $\mathrm{NO}_{3}$ Changes & $\mathrm{NH}_{4}$ Changes \\
\hline N1 & $\begin{array}{l}\text { Historic to } 2000 \text { levels and constant } \\
\text { thereafter }\end{array}$ & $\begin{array}{l}\text { Historic to } 2007 \text { levels, increased to } \\
110 \% \text { of } 2000 \text { levels by } 2020 \text {, constant } \\
\text { thereafter. }\end{array}$ \\
\hline N2 & $\begin{array}{l}\text { Historic to } 2007 \text { levels, reduced to } \\
50 \% \text { of } 2000 \text { levels by } 2020 \text {, constant } \\
\text { thereafter. }\end{array}$ & $\begin{array}{l}\text { Historic to } 2007 \text { levels, increased to } \\
110 \% \text { of } 2000 \text { levels by } 2020 \text {, constant } \\
\text { thereafter. }\end{array}$ \\
\hline N3 & $\begin{array}{l}\text { Historic to } 2007 \text { levels, reduced to } \\
25 \% \text { of } 2000 \text { levels by } 2020 \text {, constant } \\
\text { thereafter. }\end{array}$ & $\begin{array}{l}\text { Historic to } 2007 \text { levels, increased to } \\
110 \% \text { of } 2000 \text { levels by } 2020 \text {, constant } \\
\text { thereafter. }\end{array}$ \\
\hline N4 & $\begin{array}{l}\text { Historic to } 2007 \text { levels, reduced to } \\
50 \% \text { of } 2000 \text { levels by } 2020 \text {, constant } \\
\text { thereafter. }\end{array}$ & $\begin{array}{l}\text { Historic to } 2007 \text { levels, reduced to } 50 \% \\
\text { of } 2000 \text { levels by } 2020 \text {, constant } \\
\text { thereafter. }\end{array}$ \\
\hline
\end{tabular}


Figure S2-1 shows five select simulation results from the MAGIC model with varying levels of sulfur deposition. The upper graphic reports the cumulative distribution of ANC levels across the subsample of 126 sites of that are not naturally acidic $(<50 \mu \mathrm{eq} / \mathrm{L})$. Of the 169 sites modeled, there are an additional 43 sites that are naturally acidic. One of the forecasts presents estimated stream quality for 2010 where 71 percent of the subsample is acidic. The four other forecasts project stream quality for 2100 with the nitrogen deposition held at the N2 scenario. If sulfur deposition remained at Title IV levels (scenario S5), MAGIC forecasts that the share of streams below $50 \mu \mathrm{eq} / \mathrm{L}$ will remain the about the same through 2100 . The implementation of CAIR (scenario S6), is expected to cause high-elevation stream conditions in the SAM region to improve over the next century resulting in 67 percent of streams acidic by 2100 . Reducing annual sulfur deposition by 50 percent from levels expected under CAIR (scenario S7) leads to another 3 percentage point reduction in acidic streams. Reducing deposition to 3 percent of 2000 levels by 2020 (scenario S8), which represents virtual elimination of emissions, would result in another 6 percentage point reduction in acidic streams, to 58 percent of the subsample.

The MAGIC modeling also shows, depending on the particular deposition scenario, that between 50 and 78 percent of the improvements, in terms of the number of streams that are no longer acidic, seen by 2100 are achieved by 2050 .

Figure S2-2 illustrates the percentage of the sample sites projected to have ANC levels below $50 \mu$ eq/L (i.e., the share of streams at an ANC of 50 in Figure S1-1) within the representative sample of the entire SAM region. As described above, the streams in the sample represent about 40 percent of all streams in the SAM region, and those streams that are not naturally acidic account for about 75 percent of all of the streams in the sample. The right side of the histogram is thus approximately $0.30\left(=0.40^{*} 0.75\right)$ times the left side. We see that an 
additional 50 percent reduction in the deposition of sulfates from CAIR levels starting in 2010 is expected to reduce the share of streams in the entire region that have an annual ANC

concentration of $50 \mu \mathrm{eq} / \mathrm{L}$ or less that are not naturally acidic from 21.3 percent to 19.2 percent of all streams by 2100 . Consistent with these estimates and as described in the article, in the survey we say “20 percent (60,000 streams), mostly small streams in high-elevation areas, have been affected by air pollution and are not in good condition. We call these streams the 'streams of concern."”

Even the virtual elimination of future emissions and associated deposition (i.e. deposition reduced to 3 percent of current levels) would leave about 17.3 percent of the streams in the region acidic by 2100 , a change of about 3.6 percentage points.

Figure S2-1: Cumulative ANC Distribution of Non-Naturally Acidic (ANC $<50 \mu \mathrm{eq} / \mathrm{L})$

Representative Streams in Sample for a Subset of Deposition Scenarios

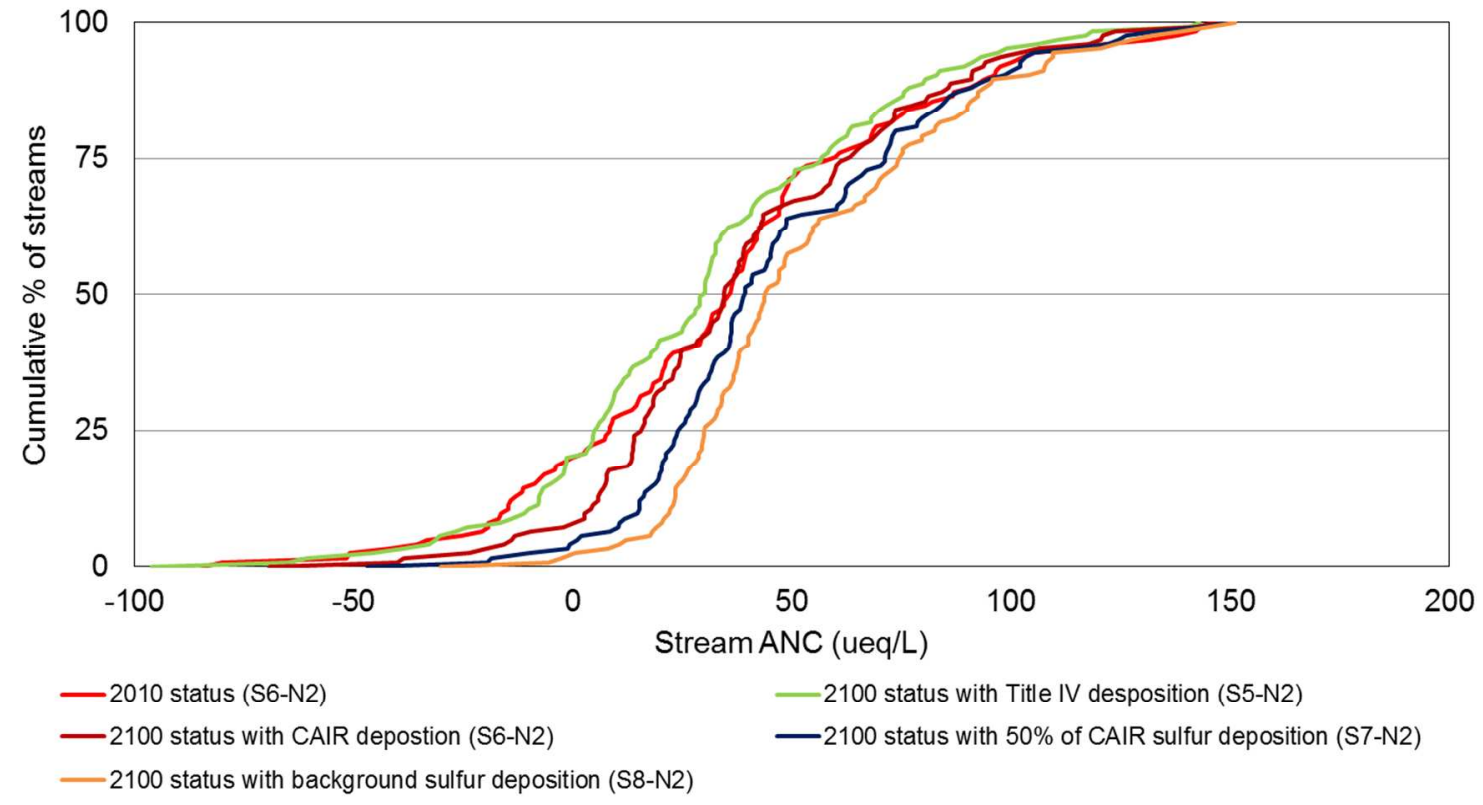


Figure S2-2: Percentage of Non-Naturally Acidic (ANC $<50 \mu \mathrm{eq} / \mathrm{L}$ ) Streams in the SAM Region for a Subset of Deposition Scenarios

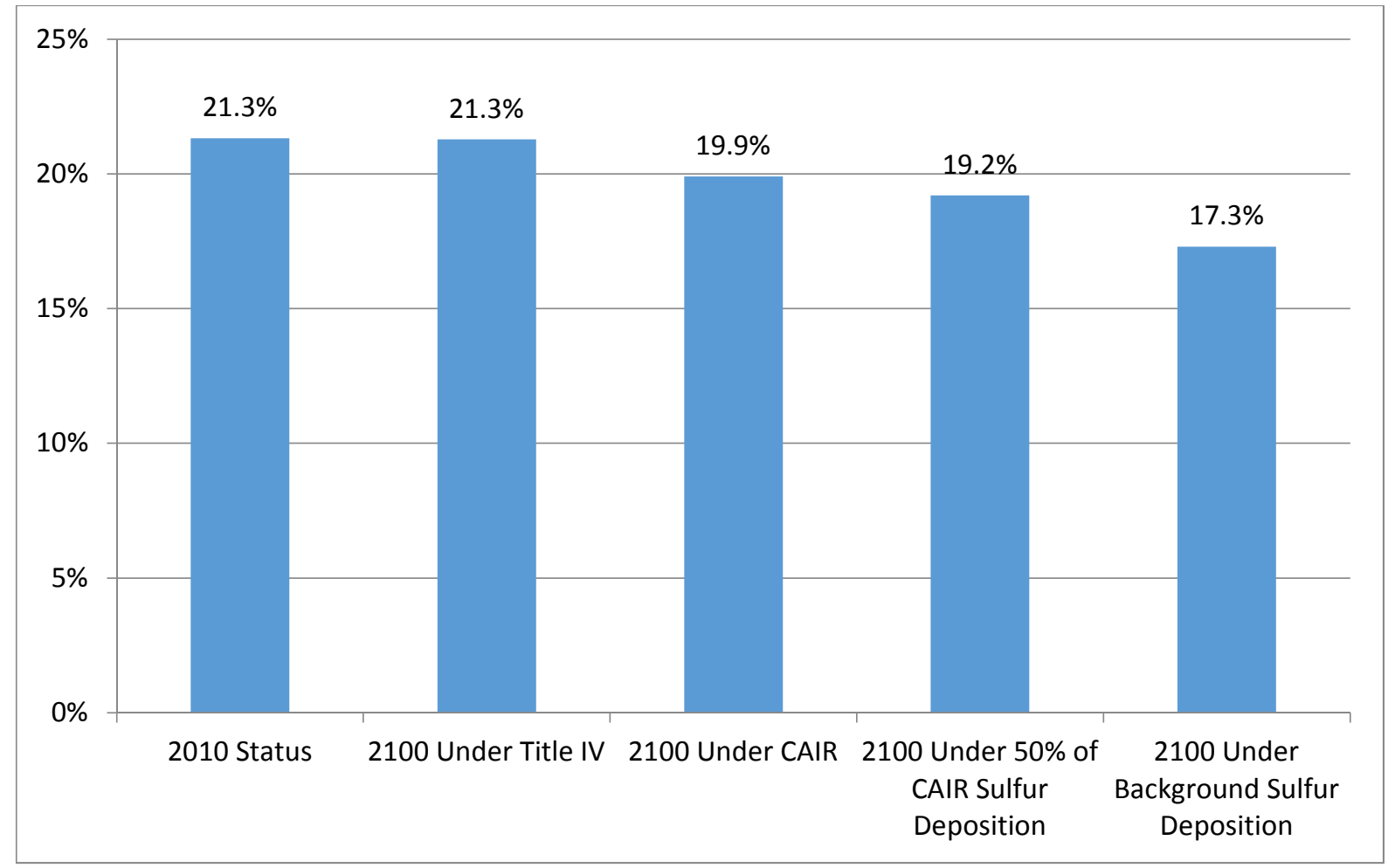

\section{Appendix S2 References}

(1) The Southern Appalachian Man and the Biosphere Program. The Southern Appalachian Assessment: Aquatic Resources Technical Report, 1996. 


\section{Appendix S3. Willingness to Pay for Ecosystem Improvements}

Table S3-1 gives the results of a larger set of willingness-to-pay models. In models I-IV, we take the simplest approach to these data and weight each choice question equally. Model I in the first column is the most basic treatment of the data, imposing homogenous preferences on all households. (In equation 1 , this model sets $\beta_{k i}=\beta_{k}, k=1 \ldots 4$, and $\boldsymbol{\gamma}=\mathbf{0}$.) These utility parameters are given at the top of the table. Note that in the conditional logit model the estimated coefficients carry no meaning beyond qualitative interpretation and their value relative to other coefficients.

For Model I, all coefficients are significant at conventional levels. A negative coefficient on the tax variable indicates households prefer programs that cost less, ceteris paribus. Positive coefficients on streams, forests, and birds indicate a positive value for those ecosystem services. A positive coefficient for the status quo scenario indicates preference for no program, regardless of the potential program's characteristics or the services it provides. The preference for the status quo may reflect nonlinearities in the preferences over attributes, mistrust of the scientific information, or low confidence in the government's ability to provide a remedy.

In principle, these utility parameters can be used to estimate the average WTP for any combination or level of improvements in any of the three ecosystem services (it is determined by the ratio of coefficients for a given ecosystem service and program costs). At the bottom of Table S3-1, we provide WTP estimates for the policy scenario described in the text. The bottom two rows of Table 1 show the average annual WTP for the full service level that would be eventually achieved under this scenario. The values are backed out from households' 10-year payment assuming a 3\% discount rate and that the service levels linearly improve to the full level in 10 years and stay constant forever thereafter. Of the two rows, the first ignores the status quo 
dummy. The second includes this dummy in the calculation and assumes households lose any utility (or disutility, in some models) associated with this scenario. These values are $\$ 24.72$ and $\$ 1.18$, respectively. Only the first is statistically significantly different from zero. The second is much lower because of the effect of the status quo dummy. Although households value ecosystem improvements, they have a disutility for change per se. These two effects roughly cancel out in Model I.

One concern in using the SP approach is hypothetical bias, the difference between how individuals respond to a survey and how they would behave in an actual choice situation. In debriefing questions, about $8 \%$ of the sample indicated that they did not vote as they would have in a real-world vote. In Model II, we drop these "invalid" respondents, which are also excluded in Models III and IV. The results are quite similar.

A related concern is that respondents might reject some of the information provided in the survey and replace it with their own beliefs. If so, the values they reveal are for a scenario different from the one for which we elicit values. In Model III, we also control statistically for the warm/cold protest factors detailed in the text. Specifically, we interact $10 \mathrm{warm} /$ cold factors, which were presented as questions to respondents, with the status quo dummy (indicating their prejudice for the status quo or any program) and with the three services as a bundle (indicating their prejudice for or against larger programs). In this case, annual WTP falls by almost a third when we ignore the status quo dummy, to $\$ 17.62$. But now the status quo dummy is close to zero, so including it only slightly reduces the annualized WTP, to $\$ 15.52$. Both estimates are statistically significant. This pattern suggests that "yea-saying" is incorporated into preferences for more ecosystem services, while "nay-saying" is incorporated into a discrete preference for the status quo. 
Model IV further accounts for unobserved heterogeneity in preferences by using a random coefficients logit model, in which some preference parameters are stochastic. This model corresponds to Model A in the text and is included here for ease of comparison. In particular, the model allows individuals' tastes for streams and forests to be log-normally distributed and for tastes for the Status Quo to be normally distributed. The results are displayed in the fourth column. (Note that the negative coefficients on the mean utility parameters for streams and forests are for a log-normal distribution, so they have to be exponentiated to be compared with the previous models.) The most notable change from the previous models is that the mean taste for the status quo falls dramatically and is now negative, thus raising the value of the program if we include this utility parameter.

Depending on the version of the survey, households responded to a varying number of choice questions, ranging from one to five. In the above models, each choice is equally weighted. Models V-VIII are the same as I-IV respectively except that they give each respondent a total weight based on how their demographics match the population. The sampling weights primarily affect the estimate of the status quo variable, with higher estimates for this parameter in each model. Consequently, WTP results in Models V-VIII are quite close to I-IV, respectively, if we ignore the status quo dummy but lower if we include it. Model VIII is equivalent to Model B in the text and is our preferred model. It allows for the most heterogeneity and uses sampling weights that best represent the population. 
Table S3-1. Estimated Utility Parameters and Willingness to Pay

\begin{tabular}{|c|c|c|c|c|c|c|c|c|}
\hline & Model I & Model II & Model III & Model IV & Model V & Model VI & Model VII & Model VIII \\
\hline $\begin{array}{l}\text { Tax } \\
\text { (dollars over } 10 \text { years) }\end{array}$ & $\begin{array}{c}-2.74 \mathrm{e}-04^{* * *} \\
(2.11 \mathrm{e}-05)\end{array}$ & $\begin{array}{c}-2.74 \mathrm{e}-04^{* * *} \\
(2.17 \mathrm{e}-05)\end{array}$ & $\begin{array}{c}-3.36 \mathrm{e}-04^{* * *} \\
(2.33 \mathrm{e}-05)\end{array}$ & $\begin{array}{c}-5.49 \mathrm{e}-04^{* * *} \\
(4.12 \mathrm{e}-05)\end{array}$ & $\begin{array}{c}-2.15 e-04^{* * *} \\
(3.88 e-05)\end{array}$ & $\begin{array}{c}-2.36 \mathrm{e}-04^{* * *} \\
(4.55 \mathrm{e}-05)\end{array}$ & $\begin{array}{c}-2.81 \mathrm{e}-04^{* * *} \\
(4.27 \mathrm{e}-05)\end{array}$ & $\begin{array}{r}-4.81 e-04^{* * *} \\
(3.63 e-05)\end{array}$ \\
\hline $\begin{array}{l}\text { Streams (number) } \\
\text { (IV and VIII: mean of In- } \\
\text { normal) }\end{array}$ & $\begin{array}{l}8.36 \mathrm{e}-06^{* * *} \\
(1.29 \mathrm{e}-06)\end{array}$ & $\begin{array}{l}8.30 \mathrm{e}-06^{* * *} \\
(1.30 \mathrm{e}-06)\end{array}$ & $\begin{array}{l}7.61 e-06^{* * *} \\
(1.13 e-06)\end{array}$ & $\begin{array}{c}-12.35^{\star * *} \\
(0.255)\end{array}$ & $\begin{array}{l}7.59 \mathrm{e}-06^{* * *} \\
(2.00 \mathrm{e}-06)\end{array}$ & $\begin{array}{l}8.66 \mathrm{e}-06^{* * *} \\
(2.29 \mathrm{e}-06)\end{array}$ & $\begin{array}{l}7.85 e-06^{* * *} \\
(1.99 e-06)\end{array}$ & $\begin{array}{c}-12.18^{* * *} \\
(0.320)\end{array}$ \\
\hline $\begin{array}{l}\text { Streams (number) } \\
\text { (SD of In-normal) }\end{array}$ & & & & $\begin{array}{l}1.501^{* * *} \\
(0.117)\end{array}$ & & & & $\begin{array}{l}1.183^{* * *} \\
(0.318)\end{array}$ \\
\hline $\begin{array}{l}\text { Forests (acres) } \\
\text { (IV and VIII: mean of In- } \\
\text { normal) }\end{array}$ & $\begin{array}{l}9.11 \mathrm{e}-07^{* * *} \\
(1.09 \mathrm{e}-07)\end{array}$ & $\begin{array}{l}9.21 \mathrm{e}-07^{\star * *} \\
(1.11 \mathrm{e}-07)\end{array}$ & $\begin{array}{l}8.48 \mathrm{e}-07^{* * *} \\
(9.19 \mathrm{e}-08)\end{array}$ & $\begin{array}{c}-14.10^{* * *} \\
(0.167)\end{array}$ & $\begin{array}{l}6.82 \mathrm{e}-07^{\star \star \star} \\
(1.60 \mathrm{e}-07)\end{array}$ & $\begin{array}{l}7.55 \mathrm{e}-07^{\star * *} \\
(1.75 \mathrm{e}-07)\end{array}$ & $\begin{array}{l}6.96 \mathrm{e}-07^{* * *} \\
(1.51 \mathrm{e}-07)\end{array}$ & $\begin{array}{c}-13.81^{* * *} \\
(0.166)\end{array}$ \\
\hline $\begin{array}{l}\text { Forests (acres) } \\
\text { (SD of In-normal) }\end{array}$ & & & & $\begin{array}{l}0.905^{\star * *} \\
(0.150)\end{array}$ & & & & $\begin{array}{c}0.191 \\
(0.554)\end{array}$ \\
\hline $\begin{array}{l}\text { Birds (percentage } \\
\text { points) }\end{array}$ & $\begin{array}{l}0.549^{* * *} \\
(0.181)\end{array}$ & $\begin{array}{l}0.511^{* * *} \\
(0.182)\end{array}$ & $\begin{array}{l}0.314^{*} \\
(0.164)\end{array}$ & $\begin{array}{l}0.537^{* * *} \\
(0.196)\end{array}$ & $\begin{array}{c}0.396 \\
(0.247)\end{array}$ & $\begin{array}{c}0.345 \\
(0.248)\end{array}$ & $\begin{array}{c}0.109 \\
(0.267)\end{array}$ & $\begin{array}{l}0.398^{* *} \\
(0.193)\end{array}$ \\
\hline $\begin{array}{l}\text { Status quo dummy } \\
\text { (IV and VIII: mean of } \\
\text { normal) }\end{array}$ & $\begin{array}{l}0.215^{* * *} \\
(0.0648)\end{array}$ & $\begin{array}{l}0.164^{\star *} \\
(0.0642)\end{array}$ & $\begin{array}{c}0.0235 \\
(0.0682)\end{array}$ & $\begin{array}{l}-0.340^{* *} \\
(0.139)\end{array}$ & $\begin{array}{l}0.259^{\star * *} \\
(0.0920)\end{array}$ & $\begin{array}{l}0.197^{* *} \\
(0.0850)\end{array}$ & $\begin{array}{l}0.0410 \\
(0.123)\end{array}$ & $\begin{array}{l}-0.133 \\
(0.151)\end{array}$ \\
\hline $\begin{array}{l}\text { Status quo dummy } \\
\text { (SD of normal) }\end{array}$ & & & & $\begin{array}{l}2.767^{* * *} \\
(0.111)\end{array}$ & & & & $\begin{array}{l}2.596^{\star * *} \\
(0.115)\end{array}$ \\
\hline $\begin{array}{l}\text { No New Taxes } \\
\text { interacted with SQ } \\
\text { dummy }\end{array}$ & & & & $\begin{array}{l}1.569^{* * *} \\
(0.198)\end{array}$ & & & & $\begin{array}{l}1.506^{\star * *} \\
(0.196)\end{array}$ \\
\hline
\end{tabular}




\begin{tabular}{|c|c|c|c|c|c|c|c|c|}
\hline & Model I & Model II & Model III & Model IV & Model V & Model VI & Model VII & Model VIII \\
\hline $\begin{array}{l}\text { Not confident in } \\
\text { government to } \\
\text { administer interacted } \\
\text { with SQ dummy }\end{array}$ & & & & $\begin{array}{l}1.903^{* * *} \\
(0.216)\end{array}$ & & & & $\begin{array}{l}1.991^{* * *} \\
(0.225)\end{array}$ \\
\hline $\begin{array}{l}\text { Believes future better } \\
\text { than survey describes } \\
\text { interacted with } S Q \\
\text { dummy }\end{array}$ & & & & $\begin{array}{l}-0.450 \\
(0.348)\end{array}$ & & & & $\begin{array}{l}-0.123 \\
(0.362)\end{array}$ \\
\hline $\begin{array}{l}\text { Believes liming program } \\
\text { wouldn't work interacted } \\
\text { with SQ dummy }\end{array}$ & & & & $\begin{array}{l}2.365^{\star \star \star} \\
(0.241)\end{array}$ & & & & $\begin{array}{l}2.258^{\star * \star} \\
(0.281)\end{array}$ \\
\hline $\begin{array}{l}\text { Believes industry } \\
\text { should bear cost } \\
\text { interacted with } \mathrm{SQ} \\
\text { dummy }\end{array}$ & & & & $\begin{array}{l}1.950^{* * *} \\
(0.321)\end{array}$ & & & & $\begin{array}{l}1.976^{* \star *} \\
(0.329)\end{array}$ \\
\hline $\begin{array}{l}\text { Believes environment } \\
\text { should be protected at } \\
\text { any cost interacted with } \\
\text { SQ dummy }\end{array}$ & & & & $\begin{array}{l}-2.182^{* * *} \\
(0.214)\end{array}$ & & & & $\begin{array}{c}-2.149^{* * *} \\
(0.216)\end{array}$ \\
\hline $\begin{array}{l}\text { Believes significant } \\
\text { human health effects } \\
\text { interacted with SQ } \\
\text { dummy }\end{array}$ & & & & $\begin{array}{c}-1.266^{\star * *} \\
(0.205)\end{array}$ & & & & $\begin{array}{c}-1.292^{\star * *} \\
(0.211)\end{array}$ \\
\hline $\begin{array}{l}\text { Believes future worse } \\
\text { than survey describes } \\
\text { interacted with } S Q \\
\text { dummy }\end{array}$ & & & & $\begin{array}{c}-1.642^{* * *} \\
(0.172)\end{array}$ & & & & $\begin{array}{c}-1.759^{* * *} \\
(0.179)\end{array}$ \\
\hline $\begin{array}{l}\text { Believes many other } \\
\text { animals harmed by } \\
\text { acidification interacted } \\
\text { with SQ dummy }\end{array}$ & & & & $\begin{array}{c}-1.113^{* * *} \\
(0.313) \\
\end{array}$ & & & & $\begin{array}{l}-0.782^{* *} \\
(0.320) \\
\end{array}$ \\
\hline $\begin{array}{l}\text { Didn't pay any taxes } \\
\text { interacted with } S Q \\
\text { dummy }\end{array}$ & & & & $\begin{array}{l}-0.264 \\
(0.247)\end{array}$ & & & & $\begin{array}{l}-0.370 \\
(0.268)\end{array}$ \\
\hline $\begin{array}{l}\text { No New Taxes } \\
\text { interacted with services } \\
\text { bundle }\end{array}$ & & & & $\begin{array}{c}9.44 \mathrm{e}-06 \\
(4.52 \mathrm{e}-05)\end{array}$ & & & & $\begin{array}{l}-3.01 e-05 \\
(4.18 e-05)\end{array}$ \\
\hline
\end{tabular}




\begin{tabular}{|c|c|c|c|c|c|c|c|c|}
\hline & Model I & Model II & Model III & Model IV & Model V & Model VI & Model VII & Model VIII \\
\hline $\begin{array}{l}\text { Not confident in } \\
\text { government to } \\
\text { administer interacted } \\
\text { with services bundle }\end{array}$ & & & & $\begin{array}{l}-1.30 \mathrm{e}-05 \\
(6.16 \mathrm{e}-05)\end{array}$ & & & & $\begin{array}{l}-5.21 \mathrm{e}-05 \\
(5.38 \mathrm{e}-05)\end{array}$ \\
\hline $\begin{array}{l}\text { Believes future better } \\
\text { than survey describes } \\
\text { interacted with services } \\
\text { bundle }\end{array}$ & & & & $\begin{array}{l}0.000101 \\
(8.80 \mathrm{e}-05)\end{array}$ & & & & $\begin{array}{l}5.50 \mathrm{e}-05 \\
(8.44 \mathrm{e}-05)\end{array}$ \\
\hline $\begin{array}{l}\text { Believes liming program } \\
\text { wouldn't work interacted } \\
\text { with services bundle }\end{array}$ & & & & $\begin{array}{l}-3.08 e-05 \\
(6.56 e-05)\end{array}$ & & & & $\begin{array}{l}-1.96 e-05 \\
(5.84 e-05)\end{array}$ \\
\hline $\begin{array}{l}\text { Believes industry } \\
\text { should bear cost } \\
\text { interacted with services } \\
\text { bundle }\end{array}$ & & & & $\begin{array}{l}8.69 \mathrm{e}-05 \\
(8.47 \mathrm{e}-05)\end{array}$ & & & & $\begin{array}{l}1.28 \mathrm{e}-05 \\
(0.000113)\end{array}$ \\
\hline $\begin{array}{l}\text { Believes environment } \\
\text { should be protected at } \\
\text { any cost interacted with } \\
\text { services bundle }\end{array}$ & & & & $\begin{array}{c}-0.000273^{* * *} \\
(3.64 \mathrm{e}-05)\end{array}$ & & & & $\begin{array}{r}-0.000229^{* \star \star} \\
(3.02 \mathrm{e}-05)\end{array}$ \\
\hline $\begin{array}{l}\text { Believes significant } \\
\text { human health effects } \\
\text { interacted with services } \\
\text { bundle }\end{array}$ & & & & $\begin{array}{l}-9.80 \mathrm{e}-05^{* * *} \\
(3.61 \mathrm{e}-05)\end{array}$ & & & & $\begin{array}{l}-7.03 e-05^{* *} \\
(3.40 e-05)\end{array}$ \\
\hline $\begin{array}{l}\text { Believes future worse } \\
\text { than survey describes } \\
\text { interacted with services } \\
\text { bundle }\end{array}$ & & & & $\begin{array}{l}-2.22 \mathrm{e}-05 \\
(3.63 \mathrm{e}-05)\end{array}$ & & & & $\begin{array}{l}1.62 \mathrm{e}-05 \\
(3.23 \mathrm{e}-05)\end{array}$ \\
\hline $\begin{array}{l}\text { Believes many other } \\
\text { animals harmed by } \\
\text { acidification interacted } \\
\text { with services bundle }\end{array}$ & & & & $\begin{array}{l}-0.000107^{* *} \\
(4.29 \mathrm{e}-05)\end{array}$ & & & & $\begin{array}{l}-0.000107^{* *} \\
(4.15 \mathrm{e}-05)\end{array}$ \\
\hline $\begin{array}{l}\text { Didn't pay any taxes } \\
\text { interacted with services } \\
\text { bundle }\end{array}$ & & & & $\begin{array}{l}-6.67 e-05 \\
(4.50 e-05)\end{array}$ & & & & $\begin{array}{l}-5.14 e-05 \\
(4.47 e-05)\end{array}$ \\
\hline $\begin{array}{l}\text { Drop invalid } \\
\text { responses? }\end{array}$ & No & Yes & Yes & Yes & No & Yes & Yes & Yes \\
\hline
\end{tabular}




\begin{tabular}{|c|c|c|c|c|c|c|c|c|}
\hline & Model I & Model II & Model III & Model IV & Model V & Model VI & Model VII & Model VIII \\
\hline Weighting & $\begin{array}{l}\text { Equal by } \\
\text { choice } \\
\text { occasions }\end{array}$ & $\begin{array}{l}\text { Equal by } \\
\text { choice } \\
\text { occasions }\end{array}$ & $\begin{array}{l}\text { Equal by } \\
\text { choice } \\
\text { occasions }\end{array}$ & $\begin{array}{l}\text { Equal by } \\
\text { choice } \\
\text { occasions }\end{array}$ & $\begin{array}{l}\text { Sample } \\
\text { weight by } \\
\text { respondent }\end{array}$ & $\begin{array}{l}\text { Sample } \\
\text { weight by } \\
\text { respondent }\end{array}$ & $\begin{array}{l}\text { Sample } \\
\text { weight by } \\
\text { respondent }\end{array}$ & $\begin{array}{c}\text { Sample } \\
\text { Weight by } \\
\text { Respondent }\end{array}$ \\
\hline $\mathrm{N}$ & 30,369 & 27,795 & 27,795 & 27,795 & 30,369 & 27,795 & 27,795 & 27,795 \\
\hline Log likelihood & -10378.9 & -9475.6 & -7427.8 & -6389.2 & -2588.1 & -2235.5 & -1688.8 & -1590.8 \\
\hline $\begin{array}{l}\text { Households' WTP for } \\
\text { the air pollution } \\
\text { scenario, on average, } \\
\text { not including SQ (95\% } \\
\text { conf. interval) }\end{array}$ & $\begin{array}{c}\$ 24.72^{* * *} \\
(20.36-29.09)\end{array}$ & $\begin{array}{c}\$ 24.56^{* * *} \\
(20.18-28.94)\end{array}$ & $\begin{array}{c}\$ 17.62^{* * *} \\
(14.35-20.89)\end{array}$ & $\begin{array}{c}\$ 16.61^{* \star *} \\
(11.65-28.12)\end{array}$ & $\begin{array}{c}\$ 25.33^{* * *} \\
(18.13-32.52)\end{array}$ & $\begin{array}{c}\$ 25.28^{* * *} \\
(18.47-32.09)\end{array}$ & $\begin{array}{c}\$ 18.16^{* * *} \\
(11.27-25.05)\end{array}$ & $\begin{array}{c}\$ 15.67^{* \star *} \\
(13.24-24.00)\end{array}$ \\
\hline $\begin{array}{l}\text { Households' WTP for } \\
\text { the air pollution } \\
\text { scenario, on average, } \\
\text { including SQ (95\% conf. } \\
\text { interval) }\end{array}$ & $\begin{array}{c}\$ 1.18 \\
(-9.36-11.71)\end{array}$ & $\begin{array}{c}\$ 6.58 \\
(-3.81-16.97)\end{array}$ & $\begin{array}{c}\$ 15.52^{* \star *} \\
(5.84-25.19)\end{array}$ & $\begin{array}{c}\$ 35.21^{* * *} \\
(22.26-51.28)\end{array}$ & $\begin{array}{c}\$-10.75 \\
(-28.59-7.09)\end{array}$ & $\begin{array}{c}\$ 0.16 \\
(-15.58- \\
15.90)\end{array}$ & $\begin{array}{c}\$ 13.78 \\
(-7.47-35.03)\end{array}$ & $\begin{array}{c}\$ 23.97^{* * *} \\
(8.14-43.14)\end{array}$ \\
\hline
\end{tabular}

Note: Standard errors shown in parentheses. ${ }^{* * *}$ Significant at $1 \%$ level; **significant at $5 \%$ level; *significant at $10 \%$ level. 


\section{Appendix S4. Details on Tests of Validity}

The validity of the stated preference (SP) procedure requires that the data follow patterns consistent with economic theory and common sense. First, survey respondents should be more supportive of an identical program at lower costs than higher costs. To test sensitivity to bid levels, we use only the first choice question so that, conservatively, only between-respondent differences are used. The large majority of respondents received one of two service levels in their first question, so we consider sensitivity to bid by each of these levels ("low" and "high" service levels respectively). Table S4-1 shows the percentage of yes-votes systematically decreasing in costs for the two scenarios shown (low versus high ecosystem services provided), with the exception of the highest bid level in the scope scenario. The third column shows the same data pooled across scenarios. Table S4-2 shows the results of a logit model, which predicts the probability of choosing the improvement program over the status quo as a function of cost, as well as a dummy variable for the level of services. The expected decreasing pattern again emerges, with each step up in the bid resulting in a drop in support. The last column shows each of these step results in a statistically significant drop from the previous step, with the exception of the final step, which is not statistically significant. Overall, these results indicate responsiveness to the cost of the program.

Second, people should be willing to pay more when more services are protected, thus exhibiting sensitivity to "scope." ${ }^{17,18}$ We again test for sensitivity to scope by using only between-respondent differences from the first choice question. The low (or base) scenario involves an improvement of $5 \%$ of all streams, $1 \%$ of all forest, and $15 \%$ of the birds' former extent. The high (or scope) scenario involves an improvement of $15 \%$ of streams, $2 \%$ of forest, 
and 30\% of the birds' former extent. Table S4-1 shows that, across bid levels, more people support the high-service scenario ( 58 percent) than the low-service scenario ( 55 percent), a statistically significant difference. Table S4-2 also shows that this result holds when controlling for bid using multivariate logistic regression.

In addition to scope tests that compare answers between respondents, our main WTP results, described in the text, show that individuals respond in the expected way to changes in the levels of the attributes protected, including numbers of streams, acres of forest, and populations of birds.

The third analysis of validity, called construct validity, looks for patterns in who is most supportive of the program. We would expect those people with higher values for the program to be more sympathetic to environmental causes and more politically progressive, more likely to participate in outdoor recreation, and more likely to frequently visit the Southern Appalachian region specifically. To test these effects, we interact variables for such demographic attributes with the Status Quo dummy in equation (1). The interaction coefficient, $\gamma$, indicates which groups (characterized by the vector $z$ ) are more likely to support the status quo (i.e., less likely to support the conservation program). We find all the above-hypothesized patterns in the data. Most $\mathrm{p}$ values corresponding to these attitudes and behaviors fall below 5\% (see Table S4-3).

Because of their income constraints and more pressing needs, one might expect that poorer households would be willing to pay less for ecosystem services than richer households. In fact, Flores and Carson ${ }^{19}$ show that economic theory does not predict this, even in cases where richer households would choose more ecosystem services at a given price. Nevertheless, the relationship is of empirical interest. Households with low income $(<\$ 35,000)$ are more likely to support the status quo relative to moderate-income household, which are equally as likely as 
high-income households to support the status quo. Those who believe their income is likely to increase over time are more likely to support the program, which is consistent with the permanent income hypothesis and with the fact that payments are spread out over 10 years. Surprisingly, perhaps, homeowners are less likely to support the program.

Those more likely to support the program over the status quo also include African Americans, men, larger households, and heads of households who have graduated from high school but not college. Virginia and Georgia residents are most likely to support the program.

\section{Appendix S4 References}

(17) Desvousges, W. H.; Johnson, F. R.; Dunford, R. W.; Boyle, K. J.; Hudson, S. P.; Wilson K. N. Measuring natural resource damages with contingent valuation: tests of validity and reliability. In Contingent Valuation: A Critical Assessment; Hausman, J. A., Eds.;

Elsevier: North-Holland, Amsterdam 1993: pp 91-159.

(18) Smith, V. K. Fifty years of contingent valuation. In Handbook on Contingent Valuation; Alberini, A., Kahn, J. R., Eds.; Elgar: Cheltenham, UK 2006, pp 7-65.

(19) Flores, N.E.; Carson, R.T. The Relationship between the Income Elasticities of Demand and Willingness to Pay. Journal of Environmental Economics and Management 1997, 33, $287-295$. 
Table S4-1. Percent Supporting program by Bid and Scope in Raw Data

\begin{tabular}{lccc}
\hline \hline & $\begin{array}{c}\text { Low-services } \\
\text { scenario }\end{array}$ & $\begin{array}{c}\text { High-services } \\
\text { scenario }\end{array}$ & Combined \\
\hline Annual cost & 75.7 & 74.4 & 75.0 \\
10 & 63.3 & 66.3 & 64.8 \\
50 & 52.1 & 57.9 & 55.1 \\
150 & 44.3 & 44.9 & 44.7 \\
350 & 38.6 & 47.1 & 43.3 \\
750 & 55.4 & 58.1 & 56.9 \\
Total & & & \\
\hline \hline
\end{tabular}

Table S4-2. Logit Model by Bid and Scope

\begin{tabular}{lccc}
\hline Variable & Parameter & $\begin{array}{c}\mathrm{p} \text {-value } \\
\mathrm{H} 0: \beta=0\end{array}$ & $\begin{array}{c}\mathrm{p} \text {-value } \\
\mathrm{H} 0: \beta_{\mathrm{b}}=\beta_{\mathrm{b}-1}\end{array}$ \\
\hline bid $=50$ & -0.484 & $<.01$ & $<.01$ \\
$\mathrm{bid}=150$ & -0.891 & $<.01$ & $<.01$ \\
$\mathrm{bid}=350$ & -1.316 & $<.01$ & $<.01$ \\
bid $=750$ & -1.371 & $<.01$ & 0.65 \\
High-services scenario & 0.135 & 0.09 & \\
Constant & 1.026 & $<.01$ & \\
\hline \hline
\end{tabular}


Table S4-3. Tests of Construct Validity and Demographic Interactions

\begin{tabular}{|c|c|c|}
\hline Variable & $\begin{array}{l}\text { Estimated } \\
\text { parameter }\end{array}$ & p-value \\
\hline \multicolumn{3}{|l|}{ Scenario variables } \\
\hline Tax (dollars per year) & $-1.38 \mathrm{e}-04$ & $(0.000)$ \\
\hline Streams (number) & $6.03 e-06$ & $(0.000)$ \\
\hline Forest (acres) & $5.71 \mathrm{e}-07$ & $(0.000)$ \\
\hline Birds (percentage point improvement) & 0.35954 & $(0.105)$ \\
\hline Status quo dummy & -0.65351 & $(0.081)$ \\
\hline \multicolumn{3}{|l|}{ Interactions with status quo } \\
\hline \multicolumn{3}{|l|}{ Environmental and political attitudes } \\
\hline Present course leads to environmental catastrophe & -0.21963 & $(0.000)$ \\
\hline Balance of nature is delicate & -0.27898 & $(0.000)$ \\
\hline Environmental crisis exaggerated & 0.33002 & $(0.000)$ \\
\hline Doesn't consider self an "environmentalist" & 0.63666 & $(0.000)$ \\
\hline Considers self a political conservative & 0.05881 & $(0.368)$ \\
\hline \multicolumn{3}{|l|}{ Participation in outdoor recreation } \\
\hline Has gone hiking & -0.13030 & (0.123) \\
\hline Has gone bird watching & -0.27586 & $(0.002)$ \\
\hline \multicolumn{3}{|l|}{ Use of Southern Appalachian area } \\
\hline Never visited & 0.00548 & $(0.965)$ \\
\hline Frequent visitor (10+ times) & -0.16535 & $(0.082)$ \\
\hline Lives in or owns property in area & -0.31866 & $(0.005)$ \\
\hline \multicolumn{3}{|l|}{ Income, wealth } \\
\hline Lower income $(<\$ 35,000)$ & 0.22012 & $(0.026)$ \\
\hline Upper income $(>\$ 125,000)$ & 0.02725 & $(0.786)$ \\
\hline Expects income to increase in future & -0.28206 & $(0.000)$ \\
\hline Owns home & 0.21137 & $(0.044)$ \\
\hline
\end{tabular}




\begin{tabular}{|l|c|c|}
\hline Other demographic variables & & $(0.320)$ \\
\hline Did not finish high school & -0.18976 & $(0.000)$ \\
\hline Graduated from college & 0.36791 & $(0.000)$ \\
\hline African American & -0.49159 & $(0.132)$ \\
\hline Hispanic & -0.40842 & $(0.018)$ \\
\hline Female & 0.18891 & $(0.003)$ \\
\hline Household size & -0.08488 & $(0.969)$ \\
\hline Georgia resident & -0.00470 & $(0.276)$ \\
\hline North Carolina resident & 0.12799 & $(0.025)$ \\
\hline Tennessee resident & 0.28303 & $0.126)$ \\
\hline West Virginia resident & 0.23669 & \\
\hline
\end{tabular}

Note: The table shows the effect of each attribute on the status quo; consequently, all signs are opposite those that would be expected for supporting the program. 